\title{
Cytoarchitecture and the patterning of fushi tarazu expression in the Drosophila blastoderm
}

\author{
Bruce A. Edgar, ${ }^{1}$ Garrett M. Odell, ${ }^{2}$ and Gerold Schubiger ${ }^{2}$ \\ Departments of ${ }^{1}$ Genetics and ${ }^{2}$ Zoology, University of Washington, Seattle, Washington 98195 USA
}

\begin{abstract}
In the Drosophila embryo at the blastoderm stage, the segmentation gene fushi tarazu (ftz) is expressed in a seven-banded pattern. The generation of this pattern, like many other segmentation gene expression patterns, coincides with the formation of cell membranes around the blastoderm nuclei. To test the role of cellularization in resolving the banded ftz pattern, we used cytoskeletal inhibitors (colcemid and cytochalasin B) to block cellularization. We found that banded $f t z$ RNA and protein patterns can form without cellular structure. We also tested the importance of rapid degradation of the ftz RNA, using cycloheximide to block degradation. RNA degradation is essential to maintain the banded $f t z$ pattern in a syncytium, but is not required to maintain the pattern in a cellularized embryo. A latticework of cytoskeletal microtubules that forms during cellularization appears to be a key component in localizing the $f t z$ mRNA. We conclude that RNA degradation and cellular structure normally work together to localize ftz RNA to its sites of synthesis.
\end{abstract}

[Key Words: fushi tarazu; cytoskeleton; cytochalasin B; colcemid; RNA degradation; RNA localization]

Received August 6, 1987; revised version accepted October 14, 1987.

In Drosophila development, complex spatial patterns of gene expression are first generated during the 14th interphase, after 13 rapid, nearly synchronous nuclear divisions. At this stage, substantial structural changes occur in the embryo, transforming the previously syncytial blastoderm into an epithelium consisting of about 6000 individual cells (Fullilove and Jacobson 1971; Turner and Mahowald 1976; Rickoll 1976; Foe and Alberts 1983). Cellularization occurs over a period of about $1 \mathrm{hr}$, and its temporal coincidence with the patterning of gene expression is striking. Only very coarse patterns of gene expression are observed in the syncytial embryo, but as cellularization progresses, finer and finer patterns are resolved (for review, see Scott and O'Farrell 1986). For example, the segmentation gene fushi tarazu $(f t z)$ is expressed in a single broad domain in the embryo during the syncytial stages of development. Midway through the cellularization process, transcription within this domain is repressed in a reiterated pattern, leaving seven bands of expression each three to four nuclei wide (Hafen et al. 1984; Edgar et al. 1986b). Notably, both cellularization and band resolution are slightly advanced in the polar regions of the embryo and along its ventral surface (Weir and Kornberg 1985). The correlation between the degree of cellularization and pattern complexity extends to other genes as well. The segmentation genes engrailed (Fjose et al. 1985; Kornberg et al. 1985) and paired (Kilchherr et al. 1986), for instance, generate 14banded patterns in which the bands are only one nucleus wide. These patterns appear later than the coarser seven-banded $f t z$ pattern, at a time when cellularization has progressed nearly to completion.

From such correlations, we anticipated that cellularization might be required to generate precise, reiterated patterns in the embryo. We reasoned that the growing cell membranes might attenuate the diffusion of zygotically produced gene regulatory factors, thereby permitting different programs of gene expression in adjacent nuclei. To test this idea, we used cytoskeletal inhibitors and a mutation to disrupt cellularization and examined the effects on the patterning of $f t z$ RNA and protein. We demonstrate that a banded $f t z$ pattern can be generated without cell formation, provided that another important process, rapid degradation of the ftz RNA (Edgar et al. 1986b), is allowed to continue. In the complementary experiment, we show that the banded pattern can be maintained without RNA degradation, provided that normal cellular organization exists. When cellularization and RNA turnover were simultaneously prevented, we found that diffusion of the $f t z$ RNA precluded resolution of the banded pattern. We propose that RNA turnover and cellular structure normally work together to check diffusion of the $f t z$ RNA, thus enhancing the ability of the embryo to resolve the banded RNA pattern.

\section{Results}

$\mathrm{ftz}$ RNA patterning coincides with cellularization

During interphase 14 , the blastoderm nuclei elongate as the plasma membrane invaginates between them, 
forming cells over a period of about $1 \mathrm{hr}$ (Fig. 1B,E,H). Membrane invagination begins within $10 \mathrm{~min}$ of entering interphase 14 [170 min after egg deposition (AED), $22^{\circ} \mathrm{C}$; as in Fig. $1 \mathrm{~B}$ ], and the membrane front reaches the basal edges of the fully elongated nuclei in about $30 \mathrm{~min}$ (200 min AED; as in Fig. 1H). Using in situ hybridization to tissue sections, we find that resolution of the sevenbanded $f t z$ RNA pattern occurs between 185 and 215 min AED, as judged by timed egg collections (Edgar et al. 1986b), and when nuclear elongation is complete, as judged morphologically (Fig. 1). Thus, the banded $f t z$ RNA pattern emerges when cellularization has pro-

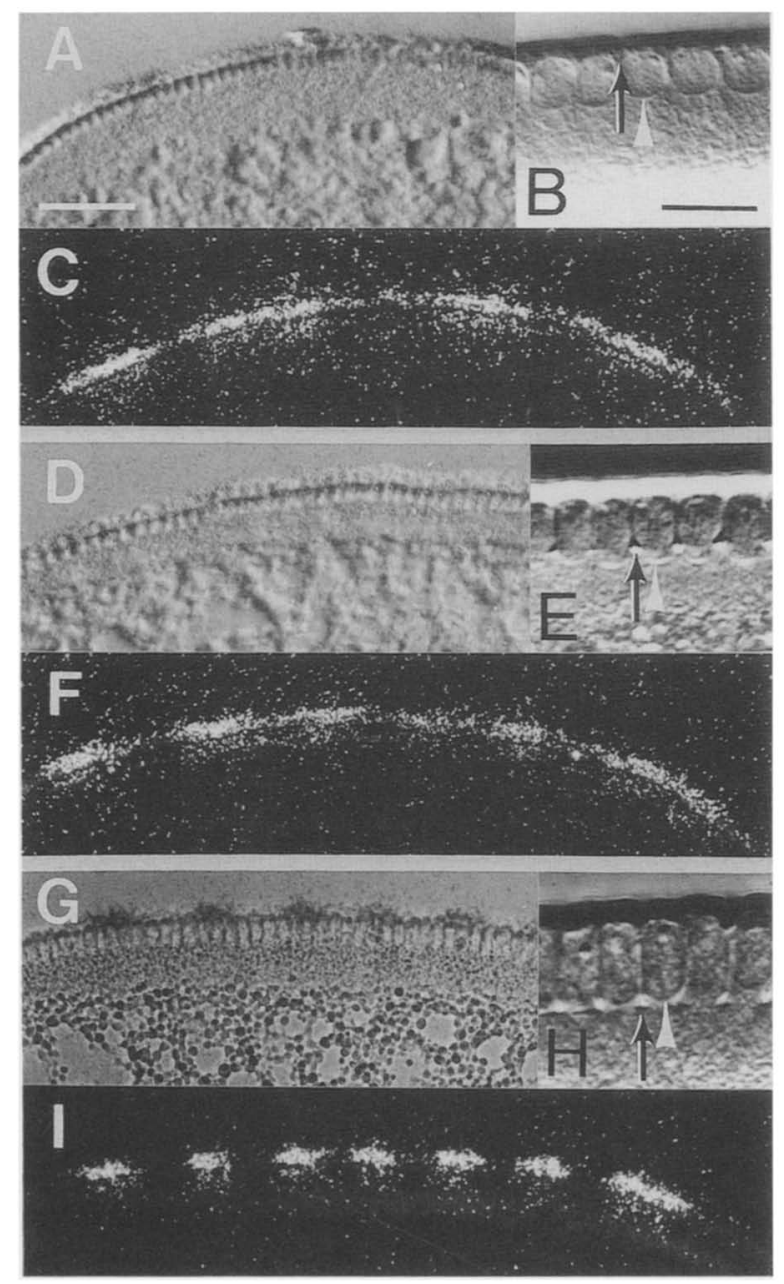

Figure 1. Generation of the banded $f t z$ RNA pattern coincides with cellularization. Panels $C, F$, and $I$ show dark-field views of the ventral surfaces of progressively older embryos after in situ hybridization with antisense ftz RNA; note the progressive addition of gaps to the RNA pattern and the cortical location of the silver grains. Panels $A, D$, and $G$ show unstained phasecontrast views of embryos $C, F$, and $I$, respectively; note the progressive elongation of nuclei (cell membranes are not visible). Scale bar (white) $=40 \mu \mathrm{m}$. Panels $B, E$, and $H$ show differential-interference contrast optics views of whole-mount embryos at stages of cellularization similar to embryos $A, D$, and $G$, respectively; black arrows indicate the level of the advancing membrane furrows; white arrowheads indicate the basal edge of the nucleus. Scale bar (black) $=10 \mu \mathrm{m}$. gressed to the degree shown in Figs. $1 \mathrm{H}$ and 2.2; at this time the nuclei are completely enclosed by cell membranes except for a basal opening to the common cytoplasm.

\section{Cytoskeletal elements and cellularization}

We used rhodamine-conjugated phalloidin and an FITC-anti-tubulin antibody to examine cytoskeletal actin and tubulin during the cellularization process. A meshwork of filamentous actin (f-actin) lines the inner surface of the plasma membrane during syncytial development (Karr and Alberts 1986), and as the plasma membrane moves into the cytoplasm during cellularization, this $\mathrm{f}$-actin meshwork remains associated with it (Fig. 2.3; Warn and Magrath 1983). At the leading edge of the membrane front, the f-actin appears to form a network of contractile ringlike structures (Fig. 2.3).

Antitubulin immunofluorescence showed that as interphase 14 begins, the centrosomes duplicate and move into the apical periplasm (periplasm is the peripheral cytoplasm that lines the egg cortex; the apical periplasm lies between the apices of the nuclei and the oolemma; see Fig. 8). The centrosomes then initiate the formation of microtubules that radiate basally, to form a dense cylindrical network around each nucleus (Fig. 2.4, 2.5; Fullilove and Jacobson 1971; Stafstrom and Staehelin 1984; Warn and Warn 1985). Each microtubule network appears to have two openings, one at the apex of the nucleus, between the centrosomes, and one at the leading (basal) edge of the invaginating plasma membrane front. Microtubules associated with adjacent nuclei appear to be interwoven, forming a continuous latticework broken only by the invaginations of the plasma membrane (Fig. 2.5).

\section{Cytochalasin B and colcemid inhibit cellularization}

To test the role of cellularization in resolving the $\mathrm{ftz}$ pattern, we used cytoskeletal inhibitors that disrupted cellularization. Cytochalasin B, an inhibitor of actin polymerization, prevented all signs of membrane invagination and nuclear elongation when injected into embryos as they entered interphase 14 , at 170 min AED (Fig. 2.7; Zalokar and Erk 1976; Foe and Alberts 1983). Many nuclei in such injected embryos moved away from the oolemma, into the basal periplasm (Fig. 2.6, 2.7). f-actin in these embryos took on a disorganized, globular distribution, with some remaining at the oolemma and some moving deep into the periplasm (Fig. 2.8). The microtubule meshwork in such embryos, however, formed normally (Fig. 2.9, 2.10). This meshwork became convoluted as some nuclei moved away from the oolemma, but appeared to maintain its integrity as a continuous sheet apical to the nuclei, punctuated only by an opening at the apex of each nucleus (Fig. 2.9; see also Fig. 8). Time-lapse video recordings showed that cytochalasin B did not block saltatory vesicle transport in the periplasm. Gastrulation movements were prevented. 


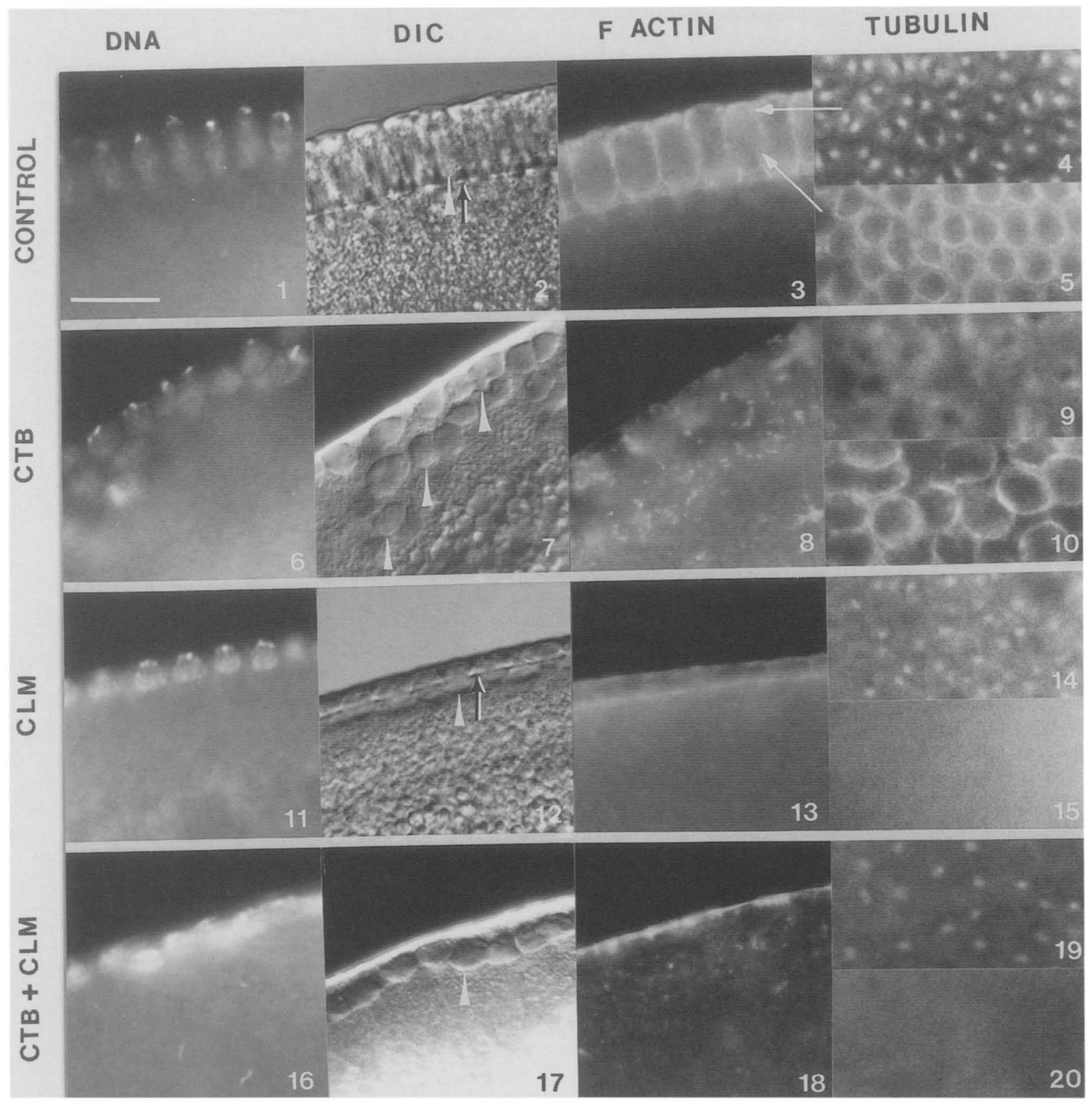

Figure 2. Cytoarchitecture of injected and control embryos. Each row represents a single embryo type: The first row (CONTROL, $1-5)$ shows an uninjected control embryo approximately $30 \mathrm{~min}$ after entry into interphase 14 (200 min AED). Other rows show experimental embryos injected with cytochalasin B (CTB, 6-10), colcemid (CLM, 11-15), or cytochalasin B and colcemid (CTB + CLM, 16-20). These were injected upon entering interphase 14 (170 min AED) and fixed about $1 \mathrm{hr}$ later (240 min AED). Each column shows a different cellular structure: DNA was stained with Hoechst 33258 (DNA), membranes were visualized using differential interference contrast optics (DIC), filamentous actin (F ACTIN) was detected with rhodamine-conjugated phalloidin (F ACTIN), and tubulin (TUBULIN) was detected by indirect immunofluorescence (TUBULIN). DNA, DIC, and F ACTIN photos are optical sections showing a small portion of the blastoderm, with the oolemma at the top. In the DIC panels, white arrowheads indicate the basal edges of nuclei and black arrows indicate the basal edges of the plasma membrane invaginations, if present. Tubulin photos show the surface of the blastoderm at focal planes just apical to the nuclei (top panels) and midway between the apical and basal ends of the nuclei (bottom panels, see white arrows in CONTROL example). Scale bar $=10 \mu \mathrm{m}$.

The microtubule inhibitor colcemid, injected at 170 min AED, just before the initiation of microtubule polymerization and membrane invagination, blocked cellularization and nuclear elongation nearly completely (Fig.
2.11-2.13). Immunofluorescence visualization of tubulin in these embryos showed very little intact microtubule structure. The centrosome, located at the apex of each nucleus, remained but was often not duplicated 
(Fig. 2.14), and the microtubule lattice was absent (Fig. 2.15). The blastoderm nuclei remained in a regular monolayer at the oolemma (Fig. 2.11, 2.12) until the onset of gastrulation movements (245 min AED), which were not entirely blocked. Colcemid injected at $170 \mathrm{~min}$ AED blocked saltatory vesicle transport (see also Foe and Alberts 1983). This was probably due to the lack of microtubules, since later injections of colcemid (at 220 min AED), after formation of the microtubule lattice, attenuated neither the lattice nor vesicle transport.

Coinjection of colcemid and cytochalasin B lat 170 min AED) blocked cellularization completely (Fig. 2.16-2.20) and allowed an orderly monolayer of syncytial nuclei, which is normally present for only 5-10 min in cycle 14, to persist for at least $3 \mathrm{hr}$ (until $360 \mathrm{~min}$ AED). In this case, $\mathrm{f}$-actin remained predominantly at the oolemma (Fig. 2.18), and little or no microtubule lattice formed (Fig. 2.19, 2.20).

We also investigated the effects of colcemid and cytochalasin B on intermediate filament distribution. Using a monoclonal antibody directed at Drosophila intermediate filaments $(2 \mathrm{H} 1$; provided by $\mathrm{W}$. Sullivan), we found that in normal cycle 14 embryos, intermediate filaments form a dense, uniformly staining mesh in the periplasm (both apical and basal), are less dense in the yolk, and do not penetrate nuclei. The same distribution was observed in embryos injected with colcemid, cytochalasin $\mathrm{B}$, or both drugs together at $170 \mathrm{~min}$ AED and fixed at 240 min AED. In normal embryos, mitotic spindles excluded intermediate filaments, but in embryos mitotically arrested by colcemid (injected at $150 \mathrm{~min}$ AED and fixed at $220 \mathrm{~min}$ AED), the intermediate filaments filled in all of the space around the mitotic chromosomes. This suggests that the intermediate filament mesh is somewhat plastic, that it can shift or flow.

\section{Banded $\mathrm{ftz}$ patterns are generated without cells}

We blocked cellularization by injecting cytochalasin B alone at the beginning of cycle 14 (170 min AED), when $f t z$ RNA is expressed in a single broad band in the embryo. After fixation in late cycle 14 (240 min AED), in situ hybridization revealed that these embryos developed irregular band/interband $f t z$ RNA patterns (Fig. 3D). We attribute this defect in patterning to the convoluted arrangement of the periplasm/nuclei layer in the blastoderm (Fig. 2.7).

When we blocked cellularization by injecting colcemid and cytochalasin B at the beginning of cycle 14 (170 min AED), we found that most of the embryos generated a six- or seven-banded $f t z$ RNA pattern $192 \%$, $n=86$; Fig. $3 \mathrm{~F})$. The positioning of the $f t z$ bands in these embryos was largely normal. However, only $6 \%$ of the injected embryos had bands as highly resolved as those seen in controls. Fifty-five percent had abnormally broad $f t z$ RNA bands (and abnormally narrow interbands), $31 \%$ had bands so broad they were nearly fused, and $8 \%$ had uniform, nonbanded expression in the $f t z-$ positive domain (15-65\% egg length). A number of embryos had banded $f t z$ expression ventrally and uniform expression dorsally. This variation in patterns most likely reflects variation in the time of injection, which was $\pm 5 \mathrm{~min}$. Embryos injected relatively late developed slightly more microtubule organization (though membrane invagination was invariably absent) and may consequently have developed more resolved $f t z$ RNA patterns. We also noted that the fourth $f t z$ band was often narrower than normal $(23 \%)$ or absent $(21 \%$; Fig. 6A). The effects on $\mathrm{ftz}$ patterning of colcemid alone (injected at $170 \mathrm{~min}$ AED/ were similar to those seen after coinjection of colcemid and cytochalasin $B$.

ftz RNA is subcellularly partitioned by the cytoskeleton

Several investigators have noted that $f t z$ mRNA and other pair-rule mRNAs accumulate predominantly in the apical periplasm (Hafen et al. 1984; Ingham et al. 1985; Weir and Kornberg 1985; Harding et al. 1986; Kilchherr et al. 1986; Macdonald et al. 1986). In normal embryos at all stages of cellularization, we also found that $f t z$ RNA was located almost exclusively in the apical periplasm (Fig. 3A,B).

In embryos injected with cytochalasin $B$ alone, we were surprised to find that, despite the chaotic distribution of nuclei, ftz RNA still accumulated apically, at the oolemma (Fig. 3C,D).

In embryos injected with colcemid or with colcemid and cytochalasin B, we found that $f t z$ RNA was not limited to the apical periplasm. Instead, we observed $f t z$ RNA in the apical periplasm, throughout the nuclear level, and to a lesser extent in the basal periplasm (Fig. $3 \mathrm{E}, \mathrm{F})$. This suggests that the microtubule lattice may be involved in limiting $f t z$ RNA to the apical periplasm.

\section{Cytoskeletal elements and RNA degradation independently sharpen the $\mathrm{ftz} R N A$ bands}

In an earlier study, we reported that $f t z$ RNA is subject to rapid degradation in vivo $\left(T_{1 / 2}=6-8 \mathrm{~min}\right)$ and suggested that this occurs uniformly throughout the embryo (Edgar et al. 1986b). The zones of high ftz RNA concentration described above thus represent a dynamic equilibrium generated by RNA synthesis, movement, and degradation. To assess the contribution of RNA movement, we employed cycloheximide to stabilize $f t z$ RNA, and $\alpha$-amanitin to block new synthesis (Edgar et al. 1986b). Cycloheximide probably stabilizes mRNAs as polysomes, thereby protecting them from ribonucleases (Ennis 1985).

When cycloheximide and $\alpha$-amanitin were coinjected into normal embryos at $240 \mathrm{~min}$ AED, ftz RNA remained banded and in the apical periplasm for a full hour postinjection $(100 \%, n=94)$. We obtained the same result after injection of cycloheximide alone $195 \%$, $n=162$; Fig. $4 \mathrm{~B}$ ), in which case $f t z$ RNA accumulated to manyfold its normal levels (Edgar et al. 1986b). Since the $f t z$ RNA did not change its distribution after stabilization, we suggest the RNA cannot diffuse in a normally cellularized embryo.

We then performed similar RNA stabilization experi- 

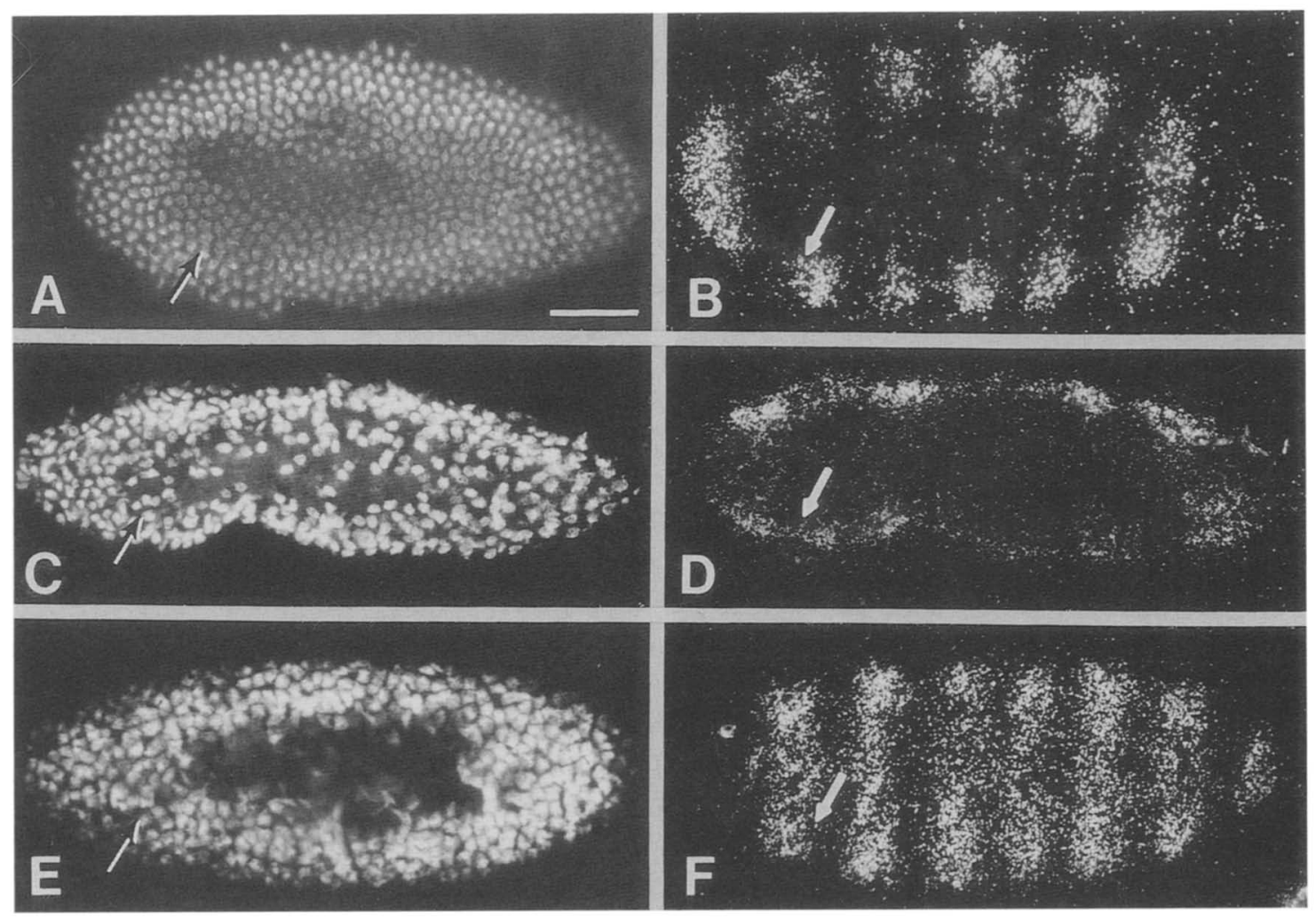

Figure 3. $f t z$ RNA is limited to the apical periplasm by cytoskeletal microtubules. We show subtangential sections of an uninjected control embryo $(A, B)$ and embryos injected with cytochalasin $\mathrm{B}(C, D)$ or colcemid and cytochalasin $\mathrm{B}(E, F)$. (Left panels) DNA stained with Hoechst 33258; (right panels) ftz RNA pattern visualized by in situ hybridization. These sections were all cut such that the central region of the section contains basal periplasm and the basal parts of nuclei, and the periphery of the section contains the oolemma, the apical periplasm, and the apical parts of nuclei. The boundary between the central region and the periphery (the upper plane of the section) is indicated by arrows. Note that in uninjected and cytochalasin B-injected embryos $(A-D)$, the $f t z$ RNA is localized exclusively to intact cortex (at the periphery of the section) and is not found where the apical periplasm has been sliced off (in the central region of the section). In the embryo injected with colcemid and cytochalasin $\mathrm{B}$, however $(E, F), f t z$ RNA is detected throughout the nuclear level and in the basal periplasm. Embryos were injected 170 min AED and fixed 240 min AED. Scale bar, 40 $\mu \mathrm{m}$.

ments on embryos treated with cytochalasin B. Cytochalasin was injected at the beginning of interphase 14 (170 min AED), and cycloheximide was delivered by a second injection at $240 \mathrm{~min} \mathrm{AED}$, after the resolution of band/ interband patterns. One hour after the second injection (at $300 \mathrm{~min}$ AED), the embryos were fixed for in situ hybridization. We found that the $f t z$ RNA remained predominantly in the apical periplasm in these embryos, but took on a nonbanded, uniform distribution there (Fig. 4D). This suggests that $f t z$ RNA can diffuse laterally, but not basally, in cytochalasin-injected embryos.

We repeated this experiment using embryos initially blocked (at 170 min AED) with colcemid and cytochalasin B. After the injection of cycloheximide (at $240 \mathrm{~min}$ AED), the banded pattern degenerated and the ftz RNA became distributed uniformly throughout both the apical and basal periplasm (98\%, $n=62$; Fig. 4F). We obtained similar results when the first injection (at 170 min AED) was of colcemid alone $(94 \%$ not banded, $n=69$ ) or when the second injection (at $240 \mathrm{~min}$ AED) was of cycloheximide and $\alpha$-amanitin $(97 \%$ not banded, $n=56)$. This shows that the $f t z$ RNA can diffuse both laterally and basally in colcemid-injected embryos.
In summary, our results suggest that the f-actinplasma membrane complex blocks lateral movement of the $f t z$ RNA and that the microtubule lattice blocks its apical to basal movement (see Table 1). This can be explained by proposing that $f t z$ RNA is sequestered in cytoplasmic compartments formed between the invaginating plasma membrane and the microtubule latticework (see Fig. 8). Indeed, such compartments can be visualized histologically (Fig. 2).

\section{A genetic block to cellularization mimics the effects of cytochalasin}

As an alternative to inhibitors, we used the maternal-effect mutation mat(3)1 to block cellularization (Rice and Garen 1975). Embryos from mat(3)1/mat(3)1 females developed nearly normally through the 13 th mitosis, but we observed neither membrane invagination nor nuclear elongation during interphase 14. f-actin exhibited a normal distribution through mitosis 13 , but became diffuse and remained along the oolemma during interphase 14. Tubulin also showed normal patterns through mitosis 13, but failed to form complete networks around 

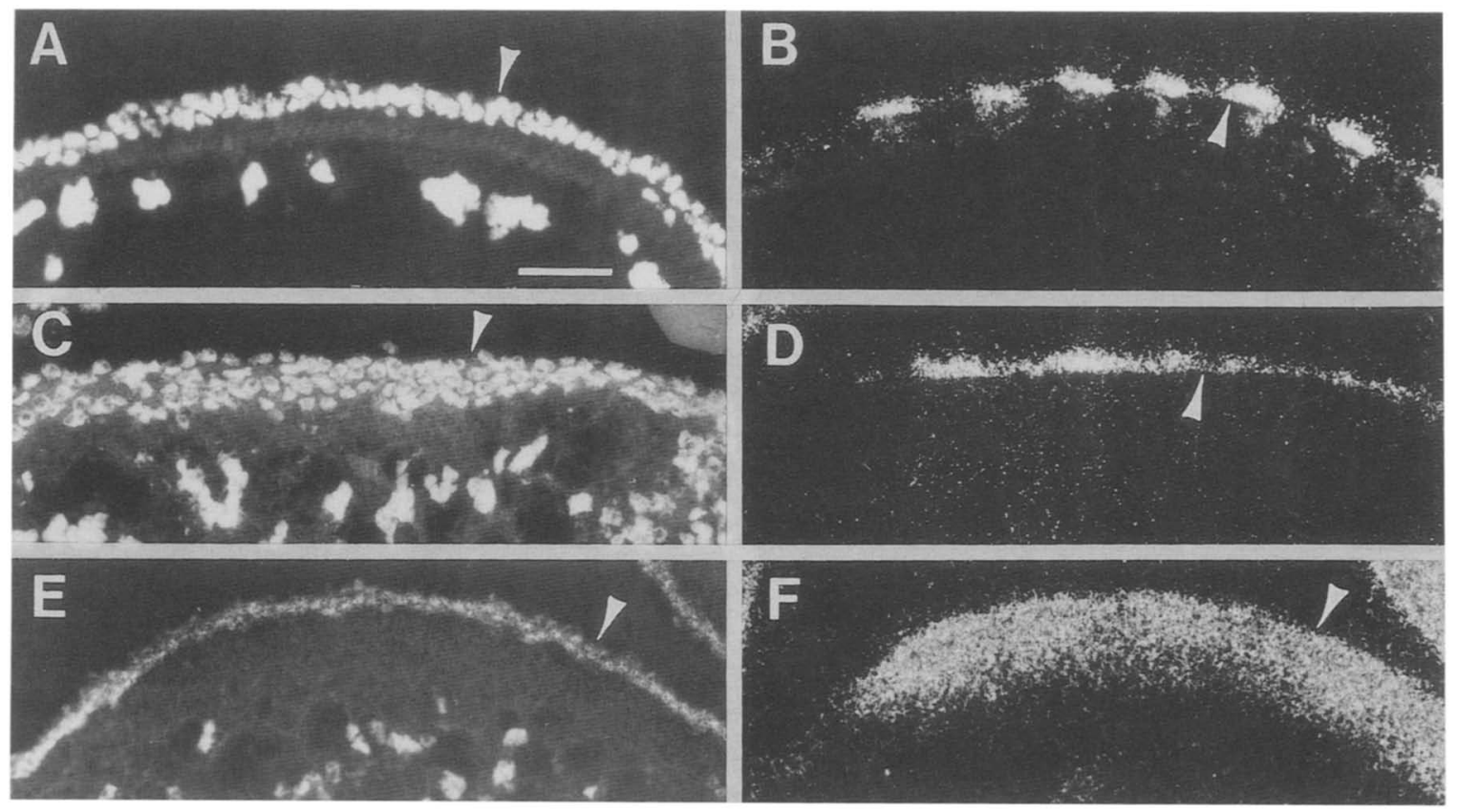

Figure 4. Movement of $f t z$ RNA is prevented by the microtubule cytoskeleton. At 170 min AED, embryos were not injected $(A, B)$, injected with cytochalasin $\mathrm{B}(C, D)$, or injected with cytochalasin $\mathrm{B}$ and colcemid $(E, F)$. All embryos were then injected with cycloheximide at $240 \mathrm{~min}$ AED (to stabilize $f t z$ RNA) and fixed at $300 \mathrm{~min}$ AED for in situ hybridization. DNA is shown to the left and $f t z$ RNA to the right. All sections are medial sagittal, rather than grazing, and show the ventral surface from 15 to $90 \%$ egg length. Arrows indicate the position of the oolemma. Note that grains in $B$ and $D$ are concentrated outside the embryo due to emissions from the apical surface, whereas grains in $F$ penetrate deep into the periplasm. Scale bar $=40 \mu \mathrm{m}$.

the nuclei during interphase 14 . Instead, the tubulin remained along the oolemma, forming an irregular meshwork with nucleus-sized holes in it. About 10 min after entry into interphase 14 , the blastoderm nuclei were swept about, causing an uneven, convoluted distribution (Fig. 5A) similar to that seen in wild-type embryos injected with cytochalasin B (Fig. 4C).
Few mat(3)1 embryos developed detectable band/interband $f t z$ RNA patterns, and those that did exhibited highly irregular patterns $\mid n=72$; one of the most normal examples is shown in Fig. 5B/. However, we found that the abnormal movement of nuclei observed in these embryos could be prevented by injecting them with colcemid as they entered interphase 14 (Fig. 5C).

Table 1. Subcellular distributions of $\mathrm{ftz} R N A$ in experimental and control embryos

\begin{tabular}{|c|c|c|c|c|c|}
\hline $\begin{array}{l}\text { First injection } \\
(170 \text { min AED })\end{array}$ & $\begin{array}{l}\text { Second injection } \\
\text { (240 min AED) }\end{array}$ & $\begin{array}{c}\text { Fixed } \\
(\min \text { AED })\end{array}$ & $\begin{array}{l}f t z \text { RNA } \\
\text { pattern }\end{array}$ & $\begin{array}{c}\text { Major RNA } \\
\text { location }\end{array}$ & Figure \\
\hline None & None & 240 & banded & $\mathrm{AP}$ & $1 \mathrm{I}, 3 \mathrm{~B}$ \\
\hline None & $\mathrm{CYH}$ & 300 & banded & $\mathrm{AP}$ & $4 \mathrm{~B}$ \\
\hline None & $\mathrm{CYH}+\alpha-\mathrm{A}$ & 300 & banded & $\mathrm{AP}$ & - \\
\hline CTB & None & 240 & irregular bands & AP & $3 \mathrm{D}$ \\
\hline $\mathrm{CTB}$ & $\mathrm{CYH}$ & 300 & uniform & AP & $4 \mathrm{D}$ \\
\hline $\mathrm{CTB}$ & $\mathrm{CYH}+\alpha-\mathrm{A}$ & 300 & uniform & $\mathrm{AP}$ & - \\
\hline CLM & None & 240 & banded & $\mathrm{AP}, \mathrm{N}, \mathrm{BP}$ & - \\
\hline CLM & $\mathrm{CYH}$ & 300 & uniform & $\mathrm{AP}, \mathrm{N}, \mathrm{BP}$ & - \\
\hline CLM & $\mathrm{CYH}+\alpha-\mathrm{A}$ & 300 & uniform & $\mathrm{AP}, \mathrm{N}, \mathrm{BP}$ & - \\
\hline $\mathrm{CTB}+\mathrm{CLM}$ & None & 240 & banded & $\mathrm{AP}, \mathrm{N}, \mathrm{BP}$ & $3 \mathrm{~F}$ \\
\hline CTB + CLM & CYH & 300 & uniform & $\mathrm{AP}, \mathrm{N}, \mathrm{BP}$ & $4 \mathrm{~F}$ \\
\hline $\mathrm{CTB}+\mathrm{CLM}$ & $\mathrm{CYH}+\alpha-\mathrm{A}$ & 300 & uniform & $\mathrm{AP}, \mathrm{N}, \mathrm{BP}$ & - \\
\hline
\end{tabular}

Embryos were injected with cytochalasin B (CTB) and/or colcemid (CLM) at 170 min after egg deposition (AED) to block cellularization. Uninjected embryos were cellularized by $240 \mathrm{~min}$ AED. Cycloheximide (CYH) and/or $\alpha$-amanitin $(\alpha$-A) were delivered by a second injection at $240 \mathrm{~min}$ AED, after the resolution of bands. Cycloheximide stabilized $f t z$ RNA without blocking further synthesis, whereas cycloheximide and $\alpha$-amanitin together blocked RNA synthesis and degradation simultaneously. The predominant concentration of silver grains over the apical periplasm (AP), nucleus $(\mathrm{N})$, or basal periplasm (BP) is noted. These locations were deduced from grazing sections (as in Fig. 3) and medial sections (as in Fig. 4). 


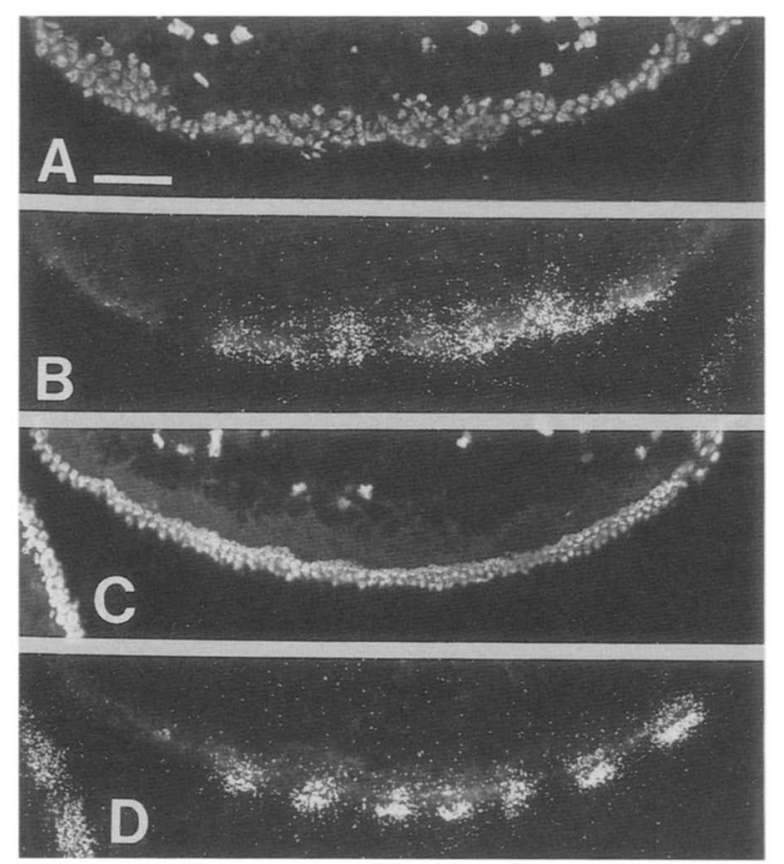

Figure 5. $f t z$ RNA patterns in mat(3)1 embryos. $(A, B)$ DNA and $f t z$ RNA in an uninjected mat/3/1 embryo fixed $240 \mathrm{~min}$ AED. $(C, D)$ DNA and $f t z$ RNA in a mat(3) 1 embryo that was injected with colcemid as it entered interphase 14 (approximately 170 min AED) and was fixed 240 min AED. Entire ventral surfaces are shown, with the posterior poles to the right. Scale bar $=50 \mu \mathrm{m}$.

This treatment rescued their ability to resolve the seven-banded $f t z$ RNA pattern $(69 \%$ resolved the banded RNA pattern, $n=57$; Fig. $5 D$ ).

\section{$\mathrm{ftz}$ protein is unstable}

Like the $f t z$ mRNA, $f t z$ protein was localized in a banded distribution in embryos injected with colcemid and cytochalasin B (Fig. 6A). In both injected and control embryos we detected the protein only in nuclei, but the amount of protein was less in injected embryos, and the band/interband borders were less distinct /compare Fig. $6 \mathrm{~A}$ and $6 \mathrm{~B})$.

From the experiments described above it is clear that RNA degradation can contribute to resolution of the banded $f t z$ RNA pattern. To see whether degradation plays a similar role in localizing the $f t z$ protein, we determined the stability of the protein by the following method. Embryos were injected with cycloheximide, to block protein synthesis, and fixed after $20 \mathrm{~min}$. The $f t z$ protein remaining was then assayed in situ by immunofluorescence, and the relative intensity of fluorescence in bands and interbands was measured in situ using a microscope photometer. Twenty minutes after injection, visible bands of $f t z$ protein had disappeared completely. Given the sensitivity of our measurements (Table 2), this implies a protein half-life of $<10 \mathrm{~min}$. A similar result was obtained for engrailed (en) protein, which, unlike $f t z$, normally maintains high steady-state levels throughout early development.
Prohibiting $\mathrm{ftz}$ expression in the blastoderm induces $\mathrm{ftz}$ expression in the yolk nuclei

Injection of colcemid at the end of the 13th interphase (150 min AED) arrested the blastoderm nuclei in metaphase 13 (165-170 min AED), but left the yolk nuclei in the interphase configuration (Fig. 7C). In these embryos, $f t z$ RNA and $f t z$ protein accumulated in the yolk nuclei, but not in or around the metaphase-arrested blastoderm nuclei (Fig. 7A,B). Injection during the 13th mitotic wave arrested only the last nuclei to divide, located in the midregion of the embryo, whereas nuclei in the polar regions progressed into interphase 14 . These embryos showed normal, banded $f t z$ expression in the interphase nuclei and no expression in the metaphase-arrested nuclei. Interestingly, expression also occurred in those yolk nuclei underlying metaphase-arrested blastoderm nuclei, but not in yolk nuclei underlying expressing interphase blastoderm nuclei (not shown).

That $f t z$ expression in the yolk and blastoderm nuclei seems to be mutually exclusive suggests a competition for positive regulators of $f t z$ transcription. Such factors might normally be concentrated in interphase blastoderm nuclei and be released transiently to the cytoplasm during mitosis (for examples of this type of behavior, see Frasch et al. 1986). The extended metaphase induced in this experiment $\mid>1 \mathrm{hr}$ as opposed to the normal 3-5 min) might allow these factors to reach the yolk nuclei by diffusion.

\section{Discussion}

Our results indicate that the cytoskeletal rearrangements of cycle 14 enhance the ability of the embryo to resolve the banded pattern of $f t z$ RNA. Specifically, we propose that $f t z$ RNA molecules are sandwiched be-

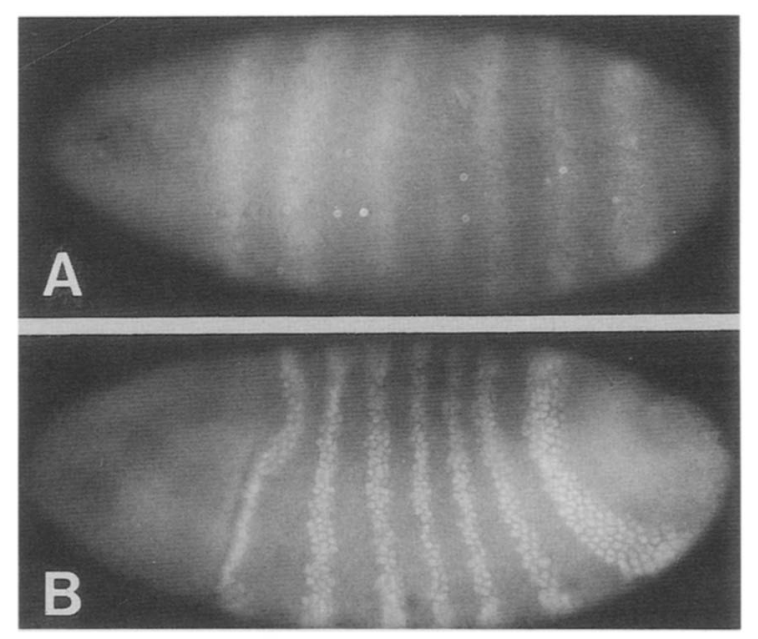

Figure 6. $f t z$ protein patterns in injected and control embryos. (A) A noncellular embryo injected with colcemid and cytochalasin B $170 \mathrm{~min}$ AED and fixed $240 \mathrm{~min}$ AED (ventral view). (B) A cellularized, uninjected embryo fixed at $240 \mathrm{~min}$ AED, just at the onset of gastrulation (lateral view). Both embryos were stained with antibodies to the $f t z$ protein. 
Table 2. Turnover of the $\mathrm{ftz}$ and en proteins

\begin{tabular}{rccr}
\hline & $f t z$ at & $f t z$ at & en at \\
& $250 \mathrm{~min}$ AED & 270 min AED & 270 min AED \\
\hline $0 \mathrm{~min}:$ & $12.0 \pm 5.9$ & $15.4 \pm 6.0$ & $16.0 \pm 5.1$ \\
$20 \mathrm{~min}:$ & $\leq 2.9^{*}$ & $\leq 4.7^{*}$ & $2.0 \pm 1.6$ \\
\hline
\end{tabular}

Embryos were injected with cycloheximide at 250 or $270 \mathrm{~min}$ AED and fixed $20 \mathrm{~min}$ later. Control embryos $(0 \mathrm{~min})$ were not injected. Values given are the mean differences between bands and their adjacent interbands and are given in lux $\times 10^{4}$. For each data point, all bands and interbands were measured in a sample of eight embryos. (*) No bands were visible above background.

tween the invaginating plasma membrane and a growing microtubule lattice and are thus immobilized at the apex of their originating nucleus (Fig. 8, CTL). We reason as follows: If $f t z$ RNA is sequestered in compartments formed between the invaginating plasma membrane and a microtubule lattice, one should expect the RNA to diffuse when the boundaries of these compartments are absent. We found exactly this. Cytochalasin blocked membrane invagination without preventing formation of the underlying microtubule lattice, resulting in a single, continuous apical periplasmic compartment accessed by all nuclei (Fig. 8, CTB). This configuration allowed $f t z$ RNA to spread laterally, but not into the basal periplasm. Colcemid blocked both formation of the micro-

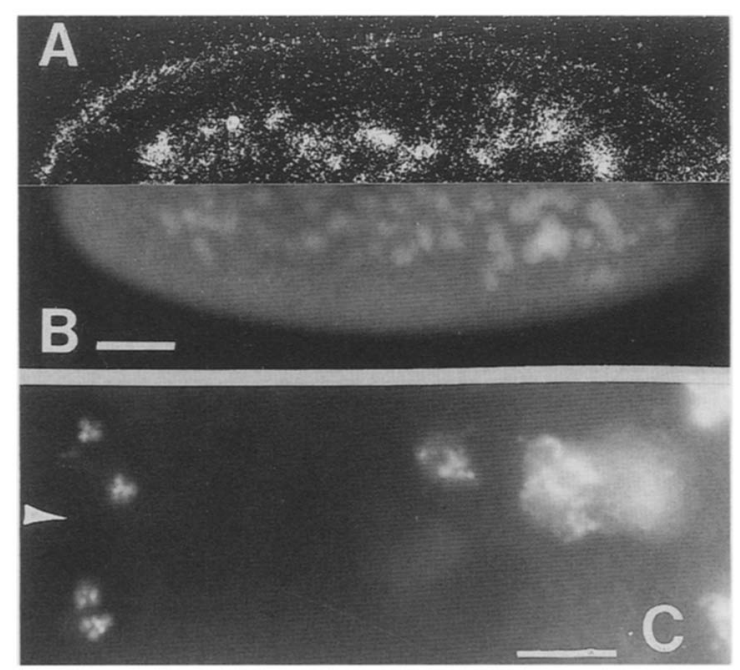

Figure 7. Induction of $f t z$ expression in the yolk nuclei. The blastoderm nuclei were arrested in metaphase by injection of colcemid just prior to the 13th mitosis ( $150 \mathrm{~min} \mathrm{AED}$ ) and fixed at 240 min AED. (A) Half of a sagittal section of such an embryo hybridized with antisense RNA $f t z$ probe. $(B)$ Half of a similar embryo stained with anti-ftz antibody. This is a whole mount, photographed at the focal plane of the yolk nuclei, which were coincident with the $f t z$ signal (not shown). Scale bar $=50 \mu \mathrm{m}$. (C) A high-magnification view of embryo $B$ with metaphase-arrested blastoderm nuclei to the left and polyploid, interphase yolk nuclei to the right. The position of the oolemma is indicated by the arrow. Scale bar $=10 \mu \mathrm{m}$. tubule lattice and membrane invagination, abolishing all compartmentalization (Fig. 8, CTB + CLM). This allowed $f t z$ RNA to spread both laterally and into the basal periplasm. Since $f t z$ RNA is very short-lived $\left(T_{1 / 2}=6\right.$ min; Edgar et al. 1986b), this spreading produced only subtle changes in the steady-state distributions of the RNA (Fig. 3). When RNA degradation was blocked by injecting cycloheximide, however, the consequences of lacking a microtubule cytoskeleton were severe: the banded pattern degenerated as $f t z$ RNA spread laterally and deep into the periplasm (Fig. 4). Similar changes in RNA distribution were observed after both RNA degradation and synthesis were blocked, implying the novel RNA distributions were due to RNA diffusion, rather than to altered patterns of transcription (Table 1).

Taken together, our results demonstrate that the apical periplasmic compartments we observed histologically (Fig. 2) are indeed functional compartments that immobilize $f t z$ RNA above the nucleus where it is synthesized. The distribution of mRNAs expressed before formation of the interphase 14 microtubule lattice, such as the Krüppel and hunchback mRNAs, is consistent with this interpretation: rather than being localized apically, these RNAs penetrate deep into the basal periplasm (Knipple et al. 1985; Tautz et al. 1987).

We can imagine several mechanisms for how the microtubule mesh might trap $f t z$ mRNA. These include the physical slowing of RNA diffusion, the binding of the RNA directly to microtubules, or the binding of the RNA to other structures that are themselves immobilized by the microtubules. Studies with cultured mammalian cells lead us to favor the latter idea: that $f t z$ RNA is bound to structures that are trapped in place between the invaginating plasma membrane and the microtubule lattice. Using cell fractionation, these studies (Cervera et al. 1981; Bonneau et al. 1985) found that newly synthesized mRNAs bound rapidly to nonmicrotubule cytoskeletal elements in the cytoplasm and remained bound during translation. Electron micrographs of cells prepared by a variety of techniques have revealed a similar picture: translationally active, polysomal mRNAs are associated with a heterogeneous array of cross-linked structural fibers (the microtrabecular lattice; Wolosewick and Porter 1979|, dominated in many cases by intermediate filaments. These intermediate filaments, in turn, appear to be cross-linked to microtubules and actin filaments (Heuser and Kirschner 1980).

Like the cytoplasm of cultured cells, the periplasm of the Drosophila blastoderm contains a dense mesh of intermediate filaments (Walter and Alberts 1984). At the level of resolution of immunofluorescence, we found that this mesh was unaffected by colcemid or cytochalasin B. If mRNAs are bound to this mesh, as they seem to be in other types of cells, then the movement of $f t z$ RNA we observed in colcemid/cytochalasin-injected embryos probably represented the drift of large complexes, consisting of intermediate filaments, $f t z$ mRNA, and ribosomes. This scenario would account for the extremely low diffusivity of $f t z$ RNA we calculated from our experiments $\left(10^{-9} \mathrm{~cm}^{2} / \mathrm{sec}\right)$. Moreover, it would sug- 
gest that the interphase microtubule skeleton traps $f t z$ RNA indirectly, by immobilizing an otherwise fluid matrix of intermediate filaments that binds the RNA.

We were surprised to find that the banded pattern of

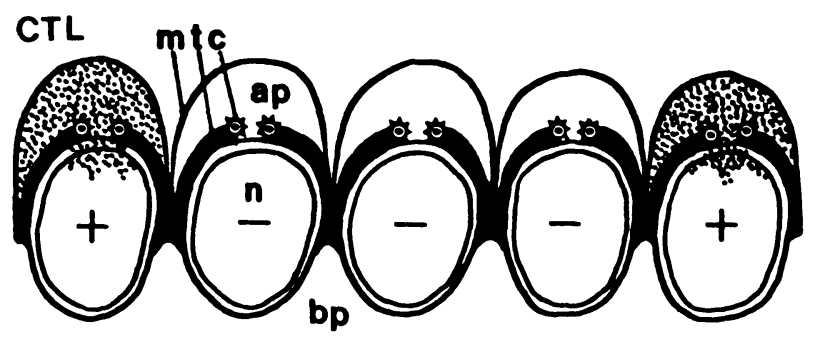

\section{CTB}

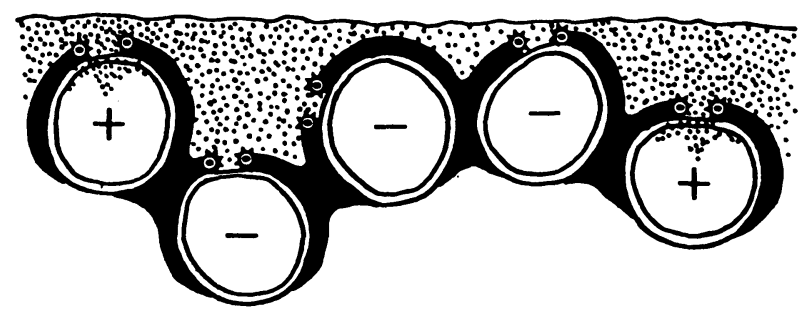

\section{CTB+ CLM}

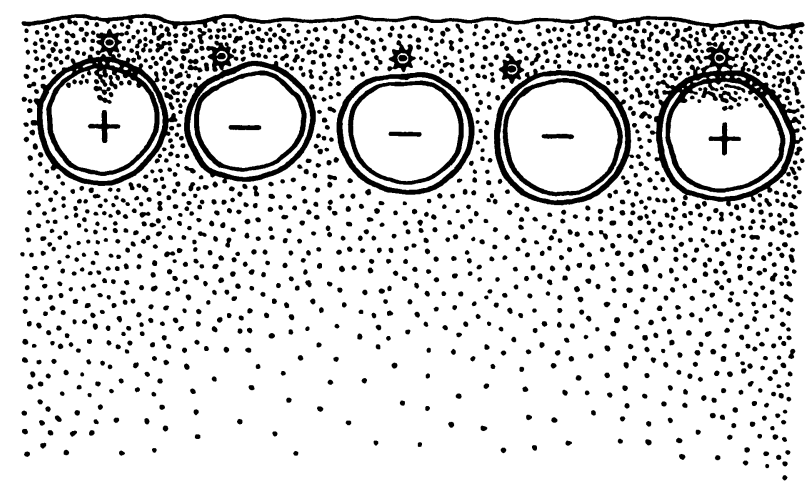

Figure 8. A schematic representation of $f t z$ RNA partitioning in normal and experimental embryos. $(T o p)$ The cytoskeletal configuration in the blastoderm of a normal embryo (CTL) shortly after the initiation of membrane invagination. (Center) The configuration resulting from injection of cytochalasin $B$ (CTB). (Bottom) The configuration resulting from injection of colcemid and cytochalasin B (CTB + CLM). Apical is up, and basal down. It is suggested that $f t z$ mRNA (dots) is transcribed in a subset of nuclei $[(\mathrm{n})$ nucleus; $|+| f t z$ producing; $(-\mid$ not $f t z$ producing], enters the apical periplasm (ap) via the opening in the tubulin mesh $(\mathrm{t})$ between the centrosomes $(\mathrm{c})$, and becomes trapped in a compartment above each nucleus. This compartment is delimited apically and laterally by the plasma membrane-actin complex $(\mathrm{m})$ and basally by the tubulin meshwork (t). Cytochalasin B disrupts membrane invagination, thereby allowing lateral movement of the $f t z$ RNA. Cytochalasin B and colcemid together disrupt both membrane invagination and formation of the tubulin mesh, allowing $f t z$ RNA to move both laterally and into the basal periplasm (bp). The distribution of $f t z$ RNA shown is that observed $1 \mathrm{hr}$ after stabilizing the RNA with cycloheximide, as in Fig. 4. $f t z$ protein also formed without cells or a microtubule cytoskeleton (Fig. 6). This observation is difficult to explain because we expect the diffusion of a small protein such as $f t z(45 \mathrm{kD})$ to be extremely rapid in a syncytium, even within an intact cytoskeletal mesh. Our experiments (Table 2) and the rapid narrowing of the ftz protein bands observed in vivo (Carroll and Scott 1985), demonstrate that $\mathrm{ftz}$ protein has a half-life of less than $10 \mathrm{~min}$. Although degradation at this rate would help to localize the protein, our calculations indicate that it would not by itself permit the degree of localization we observed (see Diffusion estimates in the Methods section). In addition to rapid degradation, rapid tight binding of the protein to relatively static structures, such as nuclei, would seem to be required to resolve the banded protein pattern. Binding of the protein to nuclei is implied by its nuclear localization in vivo, its homology to other DNA binding proteins (Laughon and Scott 1984), and the binding of $f t z \beta$-gal fusion proteins to DNA in vitro (C. Desplan and P. O'Farrell, unpubl.).

Although long-range interactions are involved in establishing pattern in the embryo during the early rapid division cycles (Schubiger and Wood 1977; Frohnhöfer and Nüsslein-Volhard, 1986; Jäckle et al. 1986), much evidence suggests that, as development progresses, pattern regulation operates on an increasingly local level. For instance, the pattern alterations caused by lacking products of the gap genes (normally expressed in cycles $11-14)$ are much larger than the normal regions of expression of those genes (Knipple et al. 1985; Jäckle et al. 1986). In contrast, the pattern alterations caused by lacking a particular pair-rule gene product (normally expressed in cycle 14) seem to be limited to those regions where that gene is normally expressed (Carroll and Scott 1986; Harding et al. 1986; Howard and Ingham 1986; Ingham et al. 1986). Thus, the range of influence of segmentation gene products seems to decrease dramatically between the syncytial and cellular blastoderm stages. This may reflect the progressive attenuation of communication between nuclei and a consequent increase in the autonomy of operation of their respective genetic programs.

We have assessed several mechanisms that contribute to the genetic autonomy of the blastoderm nuclei. These include the compartmentalization of the periplasm by microtubules and the actin-plasma membrane complex, the rapid degradation of regulatory mRNAs and proteins, and the binding of these RNAs and proteins to static substrates. Significantly, each of these factors acts increasingly strongly during interphase 14: subcellular compartmentalization becomes progressively more elaborate, rates of RNA degradation rise (Edgar et al. 1986b), and the nuclear binding of gene-regulatory proteins is for the first time not disrupted by mitoses (see DiNardo et al. 1985; Frasch et al. 1986). These changes in cytoarchitecture and metabolism seem to be required for autonomous genetic function of the blastoderm nuclei and are clearly important in the progressive refinement of pattern that occurs during the blastoderm stage of development. 


\section{Methods}

Egg collections and staging of embryos

Eggs were collected from 3-10-day old wild-type Drosophila melanogaster ("Sevelen" strain) raised in bottles. Ten-minute collections of synchronously developing embryos were obtained after precollections of $1 \mathrm{hr}$ on fresh food and 30,10, and $10 \mathrm{~min}$ on agar plates supplemented with baker's yeast and acetic acid. Development and times AED were at $21-22.5^{\circ} \mathrm{C}$. Embryos were individually staged as described by Edgar et al. (1986a) and Edgar and Schubiger (1986). mat|3)1 embryos were obtained from red mat(3)1/red mat/3)1 females crossed to red mat(3)1/TM8 males.

\section{Microinjections and histology}

Microinjections were carried out according to Edgar and Schubiger (1986). Intracellular concentrations of colcemid, cytochalasin B, cycloheximide, and $\alpha$-amanitin (Sigma) were approximately $10^{-5} \mathrm{M}, 5 \mu \mathrm{g} / \mathrm{ml}, 20 \mu \mathrm{g} / \mathrm{ml}$, and $10 \mu \mathrm{g} / \mathrm{ml}$, respectively. These were estimated according to Foe and Alberts (1983), assuming a dilution factor of $50 \times$ and even diffusion throughout the egg. Protein synthesis was inhibited $>95 \%$ by this dose of cycloheximide, and pol I and II transcription was inhibited $>95 \%$ by this dose of $\alpha$-amanitin (Edgar et al. 1986a). The colcemid dose used was fivefold that necessary to block mitosis.

Injected embryos were fixed in a two-phase mixture of $10 \%$ formaldehyde, $90 \%$ PBS and heptane for $>20 \mathrm{~min}$ and then devitellinized manually on double- stick tape. From each batch of injected embryos, some were processed for in situ hybridization (below) and others were stained with rhodamine-conjugated phalloidin to detect $\mathrm{f}$-actin (Molecular Probes) and Hoechst 33258 to detect DNA (Sigma) according to Wieschaus and Nüsslein-Volhard (1986). Tubulin was detected using a monoclonal antibody directed against $\alpha$-tubulin supplied by B.M. Alberts' lab and applied according to Karr and Alberts (1986), except that taxol was not used and fixation was in a two-phase mixture of $90 \% \mathrm{MeOH}, 50 \mathrm{~mm}$ EGTA, 1\% glutaraldehyde, and heptane for $10 \mathrm{~min}$. Intermediate filaments were detected with a Drosophila-specific monoclonal antibody $(2 \mathrm{H} 1)$ supplied by W. Sullivan. $f t z$ and en antibodies were the generous gifts of $S$. Carroll and S. DiNardo, respectively, and were used according to Carroll and Scott (1985).

\section{In situ hybridizations}

Embryos destined for in situ hybridization were postfixed for 10 min in absolute methanol, serially transferred through $100 \%$ ethanol, $50 \%$ ethanol: $50 \%$ xylene, $100 \%$ xylene, $50 \%$ xylene: $50 \%$ paraffin, and finally embedded in $100 \%$ paraffin for sectioning. Serial $8-\mu \mathrm{m}$ sections were cut using a standard AO microtome and transferred to polylysine-coated slides. After removal of the paraffin with xylene and then ethanol, sections were acetylated and hybridized in a solution containing $50 \%$ formamide, $0.6 \mathrm{M} \mathrm{NaCl}, 10 \mathrm{~mm}$ Tris (pH 7.5), $1 \mathrm{~mm}$ EDTA, $1 \%$ SDS, $10 \mathrm{~mm}$ DTT, $0.25 \mathrm{mg} / \mathrm{ml}$ E. coli tRNA, $1 \times$ Denhardt's solution, $10 \%$ PEG 6000 , and $0.1 \mathrm{ng} / \mu \mathrm{l}$ of antisense RNA probe for $24 \mathrm{hr}$ at $50^{\circ} \mathrm{C}$. The sections were then rinsed twice in $4 \times$ SSC and treated with $35 \mu \mathrm{g} / \mathrm{ml}$ RNase A for $30 \mathrm{~min}$ at $37^{\circ} \mathrm{C}$ in $0.5 \mathrm{M} \mathrm{NaCl}, 10 \mathrm{~mm}$ Tris $(\mathrm{pH} 7.5)$. Sections were then washed twice for $15 \mathrm{~min}$ in $2 \times \mathrm{SSC}, 0.05 \%$ SDS and three times for 15 $\min$ in $0.1 \times$ SSC, $0.05 \%$ SDS at $60^{\circ} \mathrm{C}$. They were dehydrated in ethanol, air-dried, and autoradiographed according to Hafen et al. (1984). We used ${ }^{35}$ S-labeled, single-stranded RNA probes with a specific activity of approximately $2 \times 10^{9} \mathrm{cpm} / \mu \mathrm{g}$ RNA. These were made with SP6 RNA polymerase (Promega) from the plasmid p65fz.1 (Edgar et al. 1986b)

Sections were stained after autoradiography and before drying with $10 \mu \mathrm{g} / \mathrm{ml}$ Hoechst 33258 for $5 \mathrm{~min}$ and destained in water for $20 \mathrm{~min}$. $0.05 \mathrm{M} \mathrm{HCl}$ was used to destain sections stained with either Hoechst 33258 or Giemsa.

\section{Diffusion estimates}

Noncellularized embryos (injected with colcemid and cytochalasin B at 170 min AED) in the process of "turning off" banded $f t z$ RNA expression (a process that occurs with similar timing and spatial progression in normal and colcemid/cytochalasin $\mathrm{B}$-injected embryos/ were injected with cycloheximide at 300 min AED. This stabilized the $f t z$ RNA, allowing its diffusion from the few isolated $f t z$ bands remaining (generally bands 2 and 7). One hour after the second injection (360 min AED), these embryos were fixed and analyzed by in situ hybridization. The same number of bands was observed as in controls at the time of injection, but the bands were expanded both laterally and basally. Lateral and basal expansion were approximately equivalent. The degree of expansion of the bands was measured using an ocular micrometer and gave a value of $35 \pm 4 \mu \mathrm{m}$ ( $n=34$ bands in 13 embryos). Nuclear diameters measured about $4.6 \mu \mathrm{m}$, and embryo lengths were 390-510 $\mu \mathrm{m}$. Similar results were obtained by injection of $\alpha$-amanitin and cycloheximide at 300 AED.

By comparing computer-drawn solutions to the diffusion equation (for a sequence of times) to the in situ hybridization grain distributions of these expanded $f t z$ RNA bands, we estimate a molecular diffusivity for $f t z$ RNA of about $10^{-9} \mathrm{~cm}^{2} / \mathrm{sec}$. This value is similar to the diffusivity of mRNAs injected into Xenopus oocytes $\left(2.4 \times 10^{-9} \mathrm{~cm}^{2} / \mathrm{sec}\right)$, which we estimated in a similar manner using data from Colman and Drummond (1986). The empirical relationship between the diffusivity, $D$, of a globular molecule (in water at room temperature) and its molecular weight, $W$, is:

$D=\left(2.23 \times 10^{-5} / W^{1 / 3}\right) \mathrm{cm}^{2} / \mathrm{sec}$

Using this formula, no known molecule can have so great a molecular weight that its diffusivity is $10^{-9} \mathrm{~cm}^{2} / \mathrm{sec}$. Such low diffusivity can only be explained by assuming that mRNAs are bound to, or trapped by, large cytoskeletal elements. The formula becomes useful, however, for computing diffusivities of proteins of $50 \mathrm{kD}$ or less. Luby-Phelps et al. (1986) found that dextran molecules in this weight class exhibited diffusivity coefficients about fourfold less in living 3T3 cells than in water. Such molecules are so small that the $40-\mathrm{nm}$ diameter pore size (the interstices between all cytoskeletal structures) LubyPhelps et al. computed for 3T3 cytoplasm presumably inhibits their movement very little.

Let us assume that $f t z$ transcription is repressed in the interband nuclei by a $50-\mathrm{kD}$ protein. This seems a reasonable assumption in light of our previous work indicating that interbands form via transcriptional repression (Edgar et al. 1986b) and work by Howard and Ingham (1986) and Carroll and Scott (1986) suggesting that the hairy gene may code for a repressor of $f t z$. Such a repressor protein would have a diffusivity coefficient in cytoplasm of fourfold less than the formula above predicts, namely: $1.5 \times 10^{-7} \mathrm{~cm}^{2} / \mathrm{sec}$. With a half-life of $T_{1 / 2}=300 \mathrm{sec}$, the distance $(L)$ such a protein would move before degradation reduced its concentration twofold is:

$L=\sqrt{D \times T_{1 / 2}}=67.4 \mu \mathrm{m}$ 
Thus, emanating from a single nucleus source, such a protein would move about 15 nucleus diameters in all directions before degradation reduced its concentration significantly. This would preclude interbands only 3.5 nuclei wide.

To be localized in bands in a syncytium, such a repressor protein must therefore bind tightly and quickly to a static substrate, such as nuclear DNA. If such a protein undergoes a firstorder binding reaction to DNA with forward (attachment) and reverse (release) rate constants $k_{+}$and $k_{-}$, then the distance it will spread from a source before twofold degradation is:

$$
L=\sqrt{\frac{D \times T_{1 / 2}}{1+\frac{k_{+}}{k_{-}+1 / T_{1 / 2}}}}
$$

Using $D=1.5 \times 10^{-7} \mathrm{~cm}^{2} / \mathrm{sec}, T_{1 / 2}=300 \mathrm{sec}$, and forcing $L$ to be less than or equal to the $4.6-\mu \mathrm{m}$ diameter of one nucleus (to permit a sharp transition from full to half $f t z$ repression between adjacent nuclei), the above formula imposes the following bounds on $k_{+}$and $k_{-}$:

$k_{+} /\left[k_{-}+(0.0033) \sec ^{-1}\right]>2100$

with $k_{+}$and $k_{-}$measured in $\sec ^{-1}$ units. Thus the ratio of forward to reverse binding constants must exceed 2100: Tight, rapid binding is essential to localize nuclear regulatory factors in a syncytium. Even with the above conditions met, the regulatory protein translated next to one nucleus will arrive, only half-attenuated, at each adjacent nucleus.

By solving partial differential equations that model $\mathrm{ftz}$ repression in a syncytium by a repressor having nuclear binding constants as just described, we have demonstrated that degradation and diffusion rates similar to those we measured and estimated $\mid T_{1 / 2}=6 \mathrm{~min}$ was assumed for both the repressor protein and $f t z$ RNA, $D=10^{-9} \mathrm{~cm}^{2} / \mathrm{sec}$ for $f t z \mathrm{RNA}$, and $D=1.5 \times 10^{-7} \mathrm{~cm}^{2} / \mathrm{sec}$ for the repressor protein) can produce the kind of fuzzy-banded $f t z$ patterns observed in the colcemid/ cytochalasin-treated embryos (Figs. 3F, 6A). To do this, we assume that interbands four nuclei wide produce the repressor autonomously. When we decrease degradation of the ftz RNA to $T_{1 / 2}=14$ min, as measured during nuclear cycle 13 (Edgar et al. 1986b), ftz RNA bands are not exhibited in our computer simulations.

\section{Acknowledgments}

We thank Sean Carroll, Steve DiNardo, and William Sullivan for gifts of antibodies and Stephanie Pino-Heiss, Margit Schubiger, Michael Weir, Karen Willows, and our reviewers for critical readings of the manuscript. We also thank Caroline Kiehle for technical help and Landin Boring for suggesting that mat(3)1 embryos might be rescued by colcemid. This work was supported by a National Science Foundation Predoctoral Fellowship to B.A.E. and a National Institutes of Health grant to G.S. (GM33656).

\section{References}

Bonneau, A.M., A. Darveau, and N. Sonenberg. 1985. Effect of viral infection on host protein synthesis and mRNA association with the cytoplasmic cytoskeletal structure. I. Cell Biol. 100: 1209-1218.

Carroll, S.B. and M.P. Scott. 1985. Localization of the fushi tarazu protein during Drosophila embryogenesis. Cell 43: $47-57$.

1986. Zygotically active genes that affect the spatial expression of the fushi tarazu segmentation gene during early Drosophila embryogenesis. Cell 45: 113-126.

Cervera, M., G. Dreyfuss, and S. Penman. 1981. Messenger RNA is translated when associated with the cytoskeletal framework in normal and VSV-infected HeLa cells. Cell 23: $113-120$.

Colman, A. and D. Drummond. 1986. The stability and movement of mRNA in Xenopus oocytes and embryos. I. Embryol. Exp. Morphol. (Suppl.) 97: 197-209.

DiNardo, S., J.M. Kuner, J. Theis, and P.H. O'Farrell. 1985. Development of embryonic pattern in $D$. melanogaster as revealed by accumulation of the nuclear engrailed protein. Cell 43: 59-69.

Edgar, B.A. and G. Schubiger. 1986. Parameters controlling transcriptional activation during early Drosophila development. Cell 44: 871-877.

Edgar, B.A., C.P. Kiehle, and G. Schubiger. 1986a. Cell cycle control by the nucleo-cytoplasmic ratio in early Drosophila development. Cell 44: 365-372.

Edgar, B. A., M.P. Weir, G. Schubiger, and T. Kornberg. 1986b. Repression and turnover pattern fushi tarazu RNA in the early Drosophila embryo. Cell 47: 747-754.

Ennis, H.L. 1985. Developmental biology of the cellular slime mold. Roche Inst. Mol. Biol. Annu. Rep. 1985, pp. 28-31.

Fjose, A., W.J. McGinnis, and W.J. Gehring. 1985. Isolation of a homeo-box containing gene from the engrailed region of Drosophila and the spatial distribution of transcripts. $\mathrm{Na}$ ture 313: 284-289.

Foe, V.E. and B.M. Alberts. 1983. Studies of nuclear and cytoplasmic behavior during the five mitotic cycles that precede gastrulation in Drosophila embryogenesis. I. Cell Sci. 61: $31-70$.

Frasch, M., D.M. Glover, and H. Saumweber. 1986. Nuclear antigens follow different pathways into daughter nuclei during mitosis in early Drosophila embryos. J. Cell Sci. 82: 155172.

Frohnhofer, H.G. and C. Nüsslein-Volhard. 1986. Organization of anterior pattern in the Drosophila embryo by the maternal gene bicoid. Nature 324: 120-125.

Fullilove, S.L. and A.G. Jacobson. 1971. Nuclear elongation and cytokinesis in Drosophila montana. Dev. Biol. 26: 560571.

Hafen, E., A. Kuroiwa, and W.J. Gehring. 1984. Spatial distribution of transcripts from the segmentation gene fushi tarazu during Drosophila embryonic development. Cell 37: 833841.

Harding, K., C. Rushlow, H.J. Doyle, T. Hoey, and M. Levine. 1986. Cross-regulatory interactions among pair-rule genes in Drosophila. Science 233: 953-959.

Heuser, J.E. and M.W. Kirschner. 1980. Filament organization revealed in platinum replicas of freeze-dried cytoskeletons. J. Cell Biol. 86: 212-234.

Howard, K. and P. Ingham. 1986. Regulatory interactions between the segmentation genes fushi tarazu, hairy, and engrailed in the Drosophila blastoderm. Cell 44: 949-957.

Ingham, P.W., K.R. Howard, and D. Ish-Horowicz. 1985. Transcription pattern of the Drosophila segmentation gene hairy. Nature 318: 439-446.

Ingham, P.W., D. Ish-Horowicz, and K.R. Howard. 1986. Correlative changes in homoeotic and segmentation gene expression in Krüppel mutant embryos of Drosophila. EMBO $\mathrm{J}$. 5: 1659-1665.

Jäckle, H., D. Tautz, H. Schuh, E. Seifert, and R. Lehmann. 
1986. Cross regulatory interactions among the gap genes of Drosophila. Nature 324: 668-670.

Karr, T.L. and B.M. Alberts. 1986. Organization of the cytoskeleton in early Drosophila embryos. J. Cell Biol. 102: 14941509.

Kilchherr, K., S. Baumgartner, D. Bopp, E. Frei, and M. Noll. 1986. Isolation of the paired gene of Drosophila and its spatial expression during early embryogenesis. Nature 321: 493-499.

Knipple, D.C., E. Seifert, U.B. Rosenburg, A. Preiss, and H. Jäckle. 1985. Spatial and temporal patterns of Krüppel gene expression in early Drosophila embryos. Nature 317: 4044.

Kornberg, T., I. Siden, P. O'Farrell, and M. Simon. 1985. The engrailed locus of Drosophila: In situ localization of transcripts reveals compartment-specific expression. Cell 40: 45-63.

Laughon, A. and M.P. Scott. 1984. Sequence of a Drosophila segmentation gene: Protein structure homology with DNAbinding proteins. Nature 310: 25-31.

Luby-Phelps, K., D.L. Taylor, and F. Lanni. 1986. Probing the structure of cytoplasm. J. Cell Biol. 102: 2015-2022.

Macdonald, P.M., P. Ingham, and G. Struhl. 1986. Isolation, structure, and expression of even-skipped: A second pairrule gene of Drosophila containing a homeo box. Cell 47: $721-734$.

Rice, T.B. and A. Garen. 1975. Localized defects of blastoderm formation in maternal-effect mutants of Drosophila. Dev. Biol. 43: 277-286.

Rickoll, W. L. 1976. Cytoplasmic continuity between embryonic cells and the primitive yolk sac during early gastrulation in Drosophila melanogaster. Dev. Biol. 49: 304-310.

Schubiger, G. and W.J. Wood. 1977. Determination during early embryogenesis of Drosophila melanogaster. Am. Zool. 17: 565-576.

Scott, M. P. and P.H. O'Farrell. 1986. Spatial programming of gene expression in early Drosophila embryogenesis. Annu. Rev. Cell Biol. 2: 49-81.

Stafstrom, J.P. and L.A. Staehelin. 1984. Dynamics of the nuclear envelope and of nuclear pore complexes during mitosis in the Drosophila embryo. Eur. I. Cell Biol. 34: 179-189.

Tautz, D., R. Lehmann, H. Schnurch, R. Schuh, E. Seifert, A. Kienlin, K. Jones, and H. Jäckle. 1987. Finger protein of novel structure encoded by hunchback, a second member of the gap class of Drosophila segmentation genes. Nature 327: 383-389.

Turner, F.R. and A.P. Mahowald, A.P. 1976. Scanning electron microscopy of Drosophila embryogenesis. I. The structure of the egg envelope and the formation of the cellular blastoderm. Dev. Biol. 50: 95-108.

Walter, M. and B.M. Alberts. 1984. Intermediate filaments in tissue culture cells and early embryos of Drosophila melanogaster. In Molecular biology of development (ed. R. Firtel and E. Davidson), pp. 263-272. UCLA Symp. Mol. Cell. Biol. New Series. Alan R. Liss, New York.

Warn, R.M. and R. Magrath. 1983. f-actin distribution during the cellularization of the Drosophila embryo visualized with FL-phalloidin. Exp. Cell Res. 143: 103-114.

Warn, R.M. and A. Warn. 1985. Microtubule arrays present during the syncytial and cellular blastoderm stage of the early Drosophila embryo. Exp. Cell Res. 163: 201-210.

Weir, M.P. and T. Kornberg. 1985. Patterns of engrailed and fushi tarazu transcripts reveal novel intermediate stages in Drosophila segmentation. Nature 318: 433-439.

Wieschaus, E. and C. Nüsslein-Volhard. 1986. Looking at embryos. In Drosophila: A practical approach (ed. D.B.
Roberts), pp. 221-223. IRL Press, Oxford.

Wolosewick, J.J. and K.R. Porter. 1979. Microtrabecular lattice of the cytoplasmic ground substance: Artifact or reality. $I$. Cell Biol. 82: 114-139.

Zalokar, M. and I. Erk. 1976. Division and migration of nuclei during early embryogenesis of Drosophila melanogaster. I. Microsc. Biol. Cell 25: 97-106. 


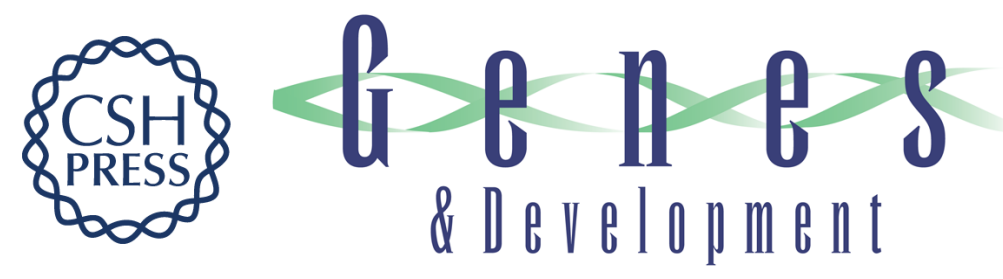

\section{Cytoarchitecture and the patterning of fushi tarazu expression in the Drosophila blastoderm.}

B A Edgar, G M Odell and G Schubiger

Genes Dev. 1987, 1:

Access the most recent version at doi:10.1101/gad.1.10.1226

References This article cites 40 articles, 8 of which can be accessed free at: http://genesdev.cshlp.org/content/1/10/1226.full.html\#ref-list-1

License

Email Alerting

Receive free email alerts when new articles cite this article - sign up in the box at the top Service right corner of the article or click here.

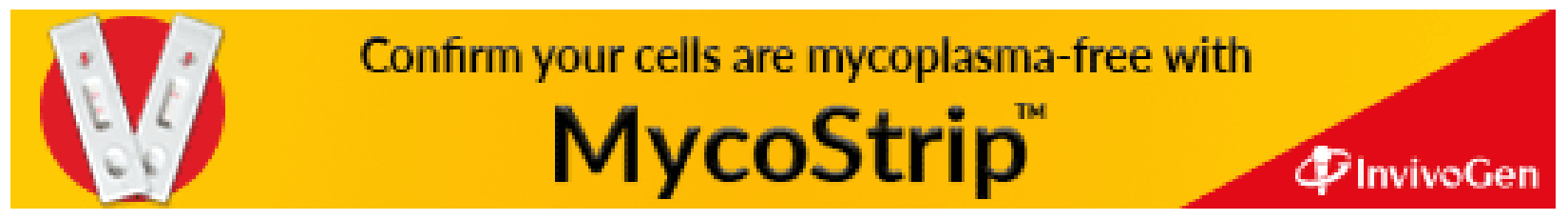

